\title{
Academic Education in Library and Information Management in Bulgaria
}

\author{
Rositsa Krasteva1, Tereza Trencheva², Sabina Eftimova², Tania Todorova² \\ ${ }^{1}$ Computer Science Department, State University of Library Studies and Information Technologies, Sofia, \\ Bulgaria \\ ${ }^{2}$ Library Management Department, State University of Library Studies and Information Technologies, Sofia, \\ Bulgaria \\ Email: r.krasteva@abv.bg, t.trencheva@unibit.bg, s.eftimova@unibit.bg, t.todorova@unibit.bg
}

Received 21 June 2014; revised 5 August 2014; accepted 21 August 2014

Copyright (C) 2014 by authors and Scientific Research Publishing Inc.

This work is licensed under the Creative Commons Attribution International License (CC BY). http://creativecommons.org/licenses/by/4.0/

(c) (i) Open Access

\section{Abstract}

The purpose of this publication is to present the contemporary aspects of training educational and qualification degree "Bachelor" of Specialty "Library and Information Management" of the Library Management Department at the State University of Library Studies and Information Technologies (SULSIT) in Sofia, Bulgaria.In view of specificity and completeness of the presented information in this publication there is a limit, which refers to the training only in educational and qualification degree "Bachelor". The following methods are used: a study of the curriculums of many universities worldwide teaching in this or a related specialty; comparative analysis; synthesis of the obtained information. Accent is put on the disciplines Intellectual Property, Standardization in Library Activities, Quality Management in Library and Information Activities, Library Psychology and Bibliotherapy. The research draws attention to some aspects insufficiently covered in the curriculum of the programs preparing future highly knowledgeable, trained library and information managers, and offers some solutions, based on our experience in the State University of Library Studies and Information Technologies, to the attention of the LIS academic and professional community.

\section{Keywords}

Library Management, Information Management, Higher Education, Bachelor's Degree, SULSIT, Bulgaria

\section{Introduction}

Socio-economic and political transformations in the Bulgarian reality necessitated a change in the functions of

How to cite this paper: Krasteva, R., Trencheva, T., Eftimova, S. and Todorova, T. (2014) Academic Education in Library and Information Management in Bulgaria. Open Journal of Social Sciences, 2, 160-171. 
libraries and enhanced their role in the process of accession to the European and World educational, cultural and economic space. Bulgaria is member of the EU since January 1st, 2007. The libraries in accordance with the principle of wide and equal public access to library and information resources, and as a democratic social institutions contribute to social stability, preservation and development of the spiritual and scientific potential of society. The contemporary challenges facing the libraries, suggest the application of adequate library management. It evolves against the background of changing the overall management paradigm —a process characteristic of global management. The outdated management approaches to the concept of "Rational Management" shall be replaced by the Marketing Paradigm, characterized by adaptability and flexibility of management. This undoubtedly imposes new requirements, including management knowledge and skills to the competencies of young specialists, finishing their high degree in specialties like Library and Information Science.

Evaluating LIS Education in Europe, the experts of the European LIS Curriculum Project conclude that in Europe, almost all library and information (LIS) programs in higher education have been developed and are offered within the context of a nation-state [1]. Several authors reported the need for internationalization of library education in Europe in accordance to achieve greater results in student and teacher mobility [2]-[4]. The situation is summarized in LIS Education in Europe: "The Structure and contents of LIS courses vary very much between the different types of LIS education providers in Europe, which include many fairly small academic environments. The apparent disparate nature of LIS educational programmes in Europe constitutes a barrier to increased cooperation in the field. There is a marked need for joint discussions of the structure and contents of LIS school curricula and for identifying and discussing possible common curricular elements both for the purpose of enhancing the quality of individual LIS educational programmes and for the sake of increased collaboration between European LIS school programmes" [5]. Based on these findings, in 2005 started the development of an international project LIS education in Europe, coordinated by the Royal School of Library and Information Science, Denmark. Main goals of the project are:

- To create better opportunities for European mobility of students and teachers;

- To increase the scale of mobility and inter-institutional cooperation;

- To develop a common conceptual framework to define the core of mandatory elements within the LIS curriculum as a basis for increasing the mobility of students and teachers and the acceleration of the Bologna process;

- To work for greater flexibility, transparency and comparability of curricula.

The results of this project were published in the European Curriculum Reflections on Library and Information Science Education [6]. In a separate section was provided information related to the training of library management. Focus is on disciplines such as Marketing Information Services; Communication Skills and Negotiations; Intellectual Property and Information Law; Quality Management and etc.

Taking into account the achievements of our colleagues in Europe, in this article we would like to share our experiences, best practices and suggestions on training in the undergraduate program "Library and Information Management" at the State University of Library Studies and Information Technologies in Sofia, Bulgaria. In response to the social and professional needs, in 2008 in the structure of the Faculty of Librarianship and Cultural Heritage (FLCH) in SULSIT is created new Department of Library Management. Founder and first head of the department was Prof. DSc Ivanka Yankova (from 2011 she is a Dean of FLCH). Since June 2011 up to nowAssoc. Prof. PhD. Tania Todorova is a Chair Holder of Library Management Department. The main task of the Library Management Department is the preparation of bachelors, masters and doctoral students in the field of library and information management.

\section{Goal, Research Tasks and Methodology of the Study}

The purpose of the study is to present the contemporary aspects of training in educational and qualification degree "Bachelor" of the Specialty "Library and Information Management" of the Library Management Department at the State University of Library Studies and Information Technologies (SULSIT) in Sofia, Bulgaria and to make comparison with the curricula of some of the biggest universities worldwide, which are accredited in LIS education. In view of specificity and completeness of the presented information in this publication there is a limit, which refers to the training only in educational and qualification degree "Bachelor". To achieve the objective are set out the following major research tasks, outlining the methodology of the study: 1) Presentation of 
the Library Management Department in SULSIT (Bulgaria) and its activity; 2) Exploration, presentation and comparative analysis of the curriculums of many universities worldwide teaching in this or a related specialty; 3 ) Conclusions and recommendations. The methodology for achieving the objective of the study and solving the set research tasks include the following specific methods: method of study and content analysis, comparative analysis; synthesis of the obtained information. Accent is put on the disciplines Intellectual Property, Standardization in Library Activities, Quality Management in Library and Information Activities, Library Psychology and Bibliotherapy. The research draws attention to some aspects insufficiently covered in the curriculum of the programs preparing future highly knowledgeable, trained library and information managers, and offers some solutions, based on our experience in the State University of Library Studies and Information Technologies, to the attention of the LIS academic and professional community.

\section{International Cooperation of the Library Management Department}

The creation and development of the Library Management Department and proposed programs-Bachelor Program "Library and Information Management” and Master Program "Library, Information and Cultural Management" are influenced by the principles and guidelines of the Bologna Declaration and the study and application of leading experience of European and foreign universities.

In the period 2009-2013, the Library Management Department was a partner in two Erasmus Intensive Programmes with the participation of European universities. The Project Das Grimm-Zentrum-(k)ein Bibliotheksmärchen) (2009-2011) with coordinator Humboldt University in Berlin (Germany) created a unique opportunity for cooperation with University of Vienna (Austria), Vilnius University (Lithuania), Masaryk University Brno (Czech Republic) [7]. In the period 2011-2013 Library Management Department at SULSIT was coordinator of Erasmus Intensive Programme "Library, Information and Cultural Heritage Management-Academic Summer School” [8]. Project Manager is Tania Todorova—Head of Library Management Department. Our partners are: Hacettepe University in Ankara (Turkey), University of Zagreb (Croatia), University Paris Descartes (France) and University of Szeget (Hungary). The mission of this project is through using a rich methodological toolkit to implement a modern educational process aimed at implementation of interdisciplinary knowledge and skills relevant to the new requirements in the career development of students in library, information and cultural sector and the policy response to higher education and the EU initiative on "New Skills for New Jobs". The main topics in IP LibCMASSare: Library, Information and Cultural Management; Information Literacy; Preservation and access to Cultural Heritage; Digital libraries; Intellectual Property; Information brokerage; Information technologies in libraries, archives, museums and other cultural institutions [9] [10].

In the process of creating and updating the curriculum of the Bachelor Program "Library and Information Management" important was the impact of active participation of professors and students from the Library Management Department in the short-term mobility under the Erasmus Intensive Programmes. On Figure 1 is shown the dynamics of the participation of professors. On Figure 2 is presented the students participation. It is necessary to highlight that in 2013 was implemented successfully 1 student mobility of an Erasmus Summer Semester in HochschulefuerMedien in Stuttgard, Germany.

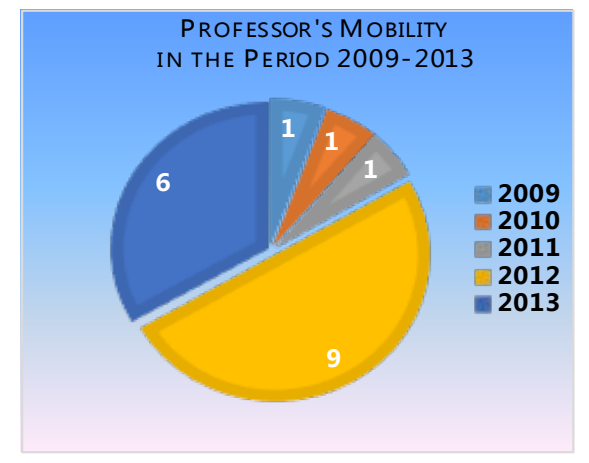

Figure 1. Professor's mobilityfor the period 2009-2013. 


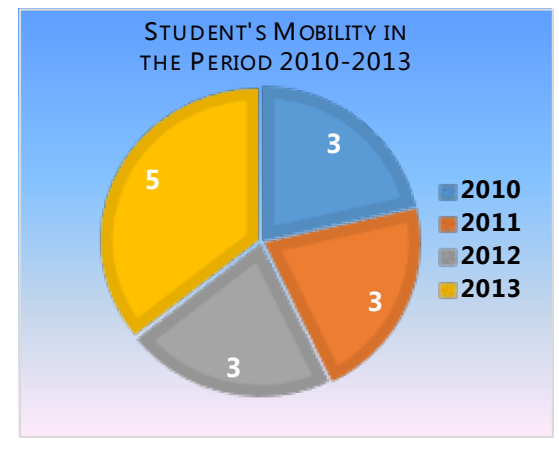

Figure 2. Student's mobilityfor the period 2010-2013.

These projects were unique opportunity for establishment a stable international network in higher education in Library and Information Sciences, Computer Sciences and Cultural Heritage Sciences and to promote cooperation between academic education and practice-library, information and cultural sector.

On 20th November 2011 the Memorandum for establishment of the UNESCO Chair' ICT in Library Studies, Education and Cultural Heritage' was signed between Irina Bokova, the General Director of UNESCO and Prof. DSc Stoyan Denchev, the Rector of the State University of Library Studies and Information Technologies. Many colleagues from Library Management Department collaborate actively in the management and in various activities and projects of the UNESCO Chair [11].

We could summarize that for five years period from the establishment of Library Management Department in SULSIT we have achieved a presence in the single educational space in the field of Library and Information Sciences and we are highly motivated for future initiatives and partnerships.

\section{Curriculum and Methodology of Library and Information Management Bachelor's Program}

The students which obtained the educational and qualification degree "Bachelor" in "Library and Information Management" in SULSIT must have a thorough scientific, theoretical and practical training in the specialty, which includes:

- Fundamental training on the nature and the diversity of libraries and other cultural institutions. History of the Field;

- Knowledge and understanding of the library cataloguing, acquisition and bibliographic processes and operations;

- Fundamentals of Library Management, Knowledge Management, Standardization and Quality Management in Library and Information Activities;

- Thorough knowledge of modern library and information technologies and their application to all facets of Library and Information Products and Services. Digitalization and Preservation of Library Funds;

- Theoretical and practical training in Information Resource Management, Information Retrieval, Assessing of Information Needs, Intellectual Property and Information Literacy;

- Specialized training in Library, Information and Project Management to acquire knowledge and skills in planning, organizing and controlling the overall operations of libraries, information centers, community centers and other cultural and public institutions;

- Basic knowledge of Marketing, Public Relations and Library Psychology for optimal organization of information and the use of methods to interact with audiences for library collections, services and events. Experts should be able:

- To raise and resolve the duties arising in connection with the organization and ensure optimal use of information resources in libraries and other organizations with arrays;

- To develop and manage projects;

- To develop and implement programs for digitization and creating their own electronic resources;

- To organize and manage various initiatives to interact the various audiences;

- Carry out self-sociological, psychological and other research needed to analyze the quality of the services 
and the extent of their approval by the users, and to be able to improve the characteristics of information and communication forms used in the library, and to bring new services or forms;

- To collaborate effectively with national and international LIS community [12].

Forms of education in educational and qualification degree "Bachelor" are regular and part time and are implemented in eight semesters. Table 1 presents the disciplines currently included in the curriculum for compulsory training of specialty "Library and Information Management” [13].

Table 1. Compulsory subjects taught in the educational and qualification degree "Bachelor" in specialty "Library and Information Management” in SULSIT.

\begin{tabular}{|c|c|}
\hline Discipline & Semester \\
\hline \multicolumn{2}{|l|}{ History of the Cultural Institutions and Librarianship } \\
\hline \multicolumn{2}{|l|}{ History and Theory of Culture } \\
\hline \multicolumn{2}{|l|}{ Information Resources } \\
\hline \multicolumn{2}{|l|}{ Annotating and Referencing of Documents } \\
\hline \multicolumn{2}{|l|}{ Information Systems } \\
\hline \multicolumn{2}{|l|}{ Book Science } \\
\hline \multicolumn{2}{|l|}{ Rare and Valuable Library Collections } \\
\hline Bulgarian Literature & Second semester \\
\hline \multicolumn{2}{|l|}{ English } \\
\hline \multicolumn{2}{|l|}{ Second Foreign Language } \\
\hline \multicolumn{2}{|l|}{ Sport } \\
\hline \multicolumn{2}{|l|}{ National Bibliography } \\
\hline \multicolumn{2}{|l|}{ Management and Library Collections Development } \\
\hline \multicolumn{2}{|l|}{ Library Management } \\
\hline \multicolumn{2}{|c|}{ Automated Libraries_-Part 1. Cataloguing, Classification and Subject Indexing of Information Recourses. } \\
\hline \multicolumn{2}{|c|}{$\begin{array}{l}\text { Automated Libraries_-Part 2. Automation Library and Information Systems. OPAC, Union Catalogues, } \\
\text { National and International Cooperation. Application of ICT in Libraries. }\end{array}$} \\
\hline Intellectual Property & Fourth semester \\
\hline \multicolumn{2}{|l|}{ Information Services in Libraries } \\
\hline \multicolumn{2}{|l|}{ Innovations for Preservation of Library Funds } \\
\hline \multicolumn{2}{|l|}{ Library Marketing } \\
\hline \multicolumn{2}{|l|}{ Information Literacy_Programs and Models } \\
\hline Architecture of the Libraries & Fifth semester \\
\hline \multicolumn{2}{|l|}{ Library Psychology } \\
\hline \multicolumn{2}{|l|}{ Practicumin various types of libraries } \\
\hline \multicolumn{2}{|l|}{ Information Management } \\
\hline \multicolumn{2}{|l|}{ Knowledge Management } \\
\hline Bibliometry & Sixth semester \\
\hline \multicolumn{2}{|l|}{ Standardization in Library Activities } \\
\hline \multicolumn{2}{|l|}{ Public Relations } \\
\hline \multicolumn{2}{|l|}{ Library Legislation } \\
\hline \multicolumn{2}{|l|}{ Quality Management of Library and Information Activities } \\
\hline \multicolumn{2}{|l|}{ Digitization and Copyright } \\
\hline \multicolumn{2}{|l|}{ Academic Writing } \\
\hline \multicolumn{2}{|l|}{ System Analysis } \\
\hline Project Management & Eight semester \\
\hline Practicum and Fieldwork. Development of Bachelor Thesis. & \\
\hline
\end{tabular}

*Teaching English and sport is foreseen as a compulsory subject for each semester. 
There is an option for the students to choose a discipline according to their interests (elective courses). Among the most popular are: Applied Software, Web Design, Content Management Systems, Intellectual Property in Internet, Libraries and Local Authorities and Communities, European Communication Policy. Common culture among students is supplemented by the chosen of them optional subjects such as: Bibliotherapy, Access to information for people with special needs etc. Methodology of teaching the students is done except to traditional methods such as lectures and seminars, and through interactive and situational methods, application of the approach "learning by doing”, “edutainment” and etc., which activates the students' participation. Individual forms of work such as term papers, presentations, individual assignments, communication in e-learning platforms - support the learning process and the current verification of students' knowledge. Library Management Department features with the active involvement of students in research projects and joint research papers for participation at scientific conferences and symposiums.

There are two initiatives of the young scientists in the Library Management Department, which are directed to the students. One of them is the work of students in relation to the Week Dedicated to The International Day of the Book and Copyright Day (23 April), with coordinator Dr. Lubomira Parizhkova, where students from all specialties take part into this initiative and have the opportunity to publish their first scientific research in the thematic research collection [14]. The second initiative is led by Dr. Tereza Trencheva and is dedicated to The International Intellectual Property Day (26 April), where the students have the opportunity to meet specialists from practice in the field of Intellectual Property [15].

For self experience activities the students of Library and Information Management visited: libraries, museums, galleries, workshops for making paper and books, book fairs (with conducting inquiries), book premieres, meetings with authors, public lectures etc. Also, they participate in the initiatives of promotion of reading - marathon of reading, book crossing movement and in different forms of stimulation of children's reading.

Important project, which is creating the opportunity to use the acquired theoretical knowledge in a real working environment is the National Project' Students' Practices' of the Bulgarian Ministry of Education and Science, implemented under the Operational Programme "Human Resources Development” of the EU. For the period July 2013-July 2014, more than 40 students of Library and Information Management Specialty conducted 240 hours internship in libraries, archives and information centers. Our students are actively involved in initiatives of the Bulgarian Library and Information Association and the Association of University Libraries, also. Our goal is nurture an active attitude towards the library profession and knowledge of the real challenges, problems and achievements in their future professional environment.

\section{Library and Information Management Specialty Worldwide}

For the purposes of this research we have studied the higher education institutions in the world, which provide training in "Library and Information Management” (LIM). In this study, we aim to gain information in which educational and qualification degree is offered training in the specialty LIM and what are the main components in the content of the curriculum. As a source of information have been used official websites of the respective universities. The results are presented in a synthesized form in Table 2.

Table 2 shows that the universities conduct training in specialty 'Library and Information Management' mainly in master educational and qualification degree. The exceptions are Hochschule der Medien in Stuttgart, Germany; Peking University and The University of Hong Kong, China; Moscow State University of Culture and Arts (Department Information and Library Management), Russia; University Technology Mara (Faculty of Information Management), Malaysia.

Practical realization of bachelors graduated in 'Library and Information Management' in Bulgaria, is particularly suitable for libraries in small towns, whose staff is limited (and often reduced to a single librarian) and it is expected to be informed and competent in a wide range of issues. As answer of these needs of library and information sphere, SULSIT offers training in Bachelor level—specialty "Library and Information Management” and in Master level_- “Library, information and Cultural Management”.

Diplomas and certificates that graduates of the corresponding universities receive are different, account the type of the training already acquired specialty and professional experience and length of the training course.

They can be:

- Bachelour diploma (training lasts 3 - 4 years);

- Graduate sertificate (training is done after obtaining a bachelor's degree or professional experience and 
Table 2. Worldwide Universities engaged in training in the specialty “Library and Information Management”.

\begin{tabular}{|c|c|c|c|}
\hline Country & Name of the University & $\begin{array}{l}\text { Educational and } \\
\text { Qualification } \\
\text { Degree }\end{array}$ & Core Curriculum Elements \\
\hline Australia & University of South Australia & Master (MA) & $\begin{array}{l}\text { - } \quad \text { Information Management } \\
\text { - } \quad \text { Accessing and Organizing Resources } \\
\text { - }\end{array}$ \\
\hline Canada & $\begin{array}{l}\text { The University of British Columbia } \\
\text { (School of Library, Archival and } \\
\text { Information Studies) }\end{array}$ & Master & $\begin{array}{ll}\text { - } & \text { Organization and Knowledge Management } \\
\text { - } & \text { Information Systems } \\
\text { - } & \text { Digital Libraries }\end{array}$ \\
\hline China & Peking University & $\begin{array}{l}\text { Bachelor (BA) } \\
\text { Master }\end{array}$ & $\begin{array}{ll}\text { - } & \text { Information Storage and Retrieval } \\
- & \text { Computer Networks } \\
\text { - } & \text { Information Economics } \\
- & \text { Management Information System } \\
- & \text { Library Management } \\
\text { - } & \text { Information Policy and Law }\end{array}$ \\
\hline China & The University of Hong Kong & $\begin{array}{l}\text { Bachelor } \\
\text { Master }\end{array}$ & $\begin{array}{l}\text { - } \quad \text { Information Science } \\
-\quad \text { Science in the Field of Management }\end{array}$ \\
\hline Denmark & $\begin{array}{l}\text { Royal School of Library and } \\
\text { Information Science }\end{array}$ & Master & $\begin{array}{l}\text { - } \quad \text { Theory of Production of Information and Knowledge } \\
\text { - } \quad \text { Analysis and Management of Information Resources } \\
\text { - } \quad \text { Information Policy and Strategy of the Organization } \\
-\quad \text { Planning, Management and Evaluation of Information } \\
\quad \text { Systems }\end{array}$ \\
\hline Germany & Hochschule der Medien in Stuttgart & $\begin{array}{l}\text { Bachelor } \\
\text { Master }\end{array}$ & $\begin{array}{l}\text { - } \quad \text { Management in Human Resources, Organization, Marketing } \\
\text { - } \quad \text { Information and Media Market } \\
\text { - } \quad \text { Library Management System Database }\end{array}$ \\
\hline India & Gujarat University & Master & $\begin{array}{ll}\text { - } & \text { Management of Library and Information Centers } \\
\text { - } & \text { Leadership and Change Management } \\
\text { - } & \text { Information and Communications Technologies and } \\
& \text { Research }\end{array}$ \\
\hline Malaysia & University Technology Mara & Bachelor & $\begin{array}{ll}\text { - } & \text { Information and Library Management } \\
\text { - } & \text { Information, Information Technology and Libraries }\end{array}$ \\
\hline Russia & $\begin{array}{c}\text { Moscow State University of Culture } \\
\text { and Arts }\end{array}$ & $\begin{array}{l}\text { Bachelor } \\
\text { Master }\end{array}$ & $\begin{array}{ll}\text { - } & \text { Library and Information Management } \\
- & \text { Library Statistics, Legislation } \\
- & \text { Economics and Marketing of Library and Information } \\
& \text { Services } \\
- & \text { Information Technology Management } \\
- & \text { PR and Advertising in the Library }\end{array}$ \\
\hline United & $\begin{array}{l}\text { University of Rhode Island (School } \\
\text { of Library and Information Studies) }\end{array}$ & Master & $\begin{array}{ll}\text { - } & \text { Management of Library and Information Services } \\
\text { - } & \text { Information Science and Technology } \\
\text { - } & \text { Types of Libraries and Library Processes and Services }\end{array}$ \\
\hline Kingdom & Robert Gordon University & Master & $\begin{array}{ll}- & \text { Information Studies } \\
- & \text { Managing Information Services } \\
- & \text { Database Construction and Use } \\
- & \text { Knowledge Organization }\end{array}$ \\
\hline USA & University of California Berkley & Master & $\begin{array}{ll}- & \text { Information and Communications Technologies } \\
- & \text { Leadership } \\
- & \text { Computer Sciences } \\
- & \text { Psychology and Sociology, Economics, Business, Law, } \\
- & \text { Library/Information Studies }\end{array}$ \\
\hline
\end{tabular}

usually lasts 6 - 8 months);

- Postgraduate diploma (training is done after obtaining a bachelor's degree or professional experience and usually lasts for 12 months);

- Master (training is done after obtaining a bachelor's degree and usually lasts 16 - 24 months);

- Professional master (training is done after obtaining a bachelor's degree and professional experience and usually lasts 12 - 18 months);

- Graduate entry master (training is done after obtaining a bachelor's degree in Library and Information Management or related specialty and usually lasts about 24 months);

- PhD and other Doctoral Research Degrees (training is done after obtaining a master's degree or completion of a bachelor's degree with special honors and usually lasts 2 - 4 years).

On the development of educational content of specialty "Library and Information Management" in SULSIT 
Table 3. Partner universities of the Library Management Department in SULSIT, who carry out training in Library Management and/or Information Management.

\begin{tabular}{|c|c|c|c|}
\hline Country & Higher School & Specialty and Level & Core Curriculum Elements \\
\hline Austria & $\begin{array}{l}\text { University of } \\
\text { Vienna }\end{array}$ & $\begin{array}{l}\text { Library and Information } \\
\text { Studies } \\
\text { MA }\end{array}$ & $\begin{array}{l}\text { - } \quad \text { Management (in Library, Information, Documentation) } \\
\text { - } \quad \text { System for Information and Documentation }\end{array}$ \\
\hline Croatia & $\begin{array}{l}\text { University of } \\
\text { Zagreb }\end{array}$ & $\begin{array}{l}\text { Library Science } \\
\text { BSc, MA, PhD }\end{array}$ & $\begin{array}{ll}\text { - } & \text { Bibliography } \\
\text { - } & \text { Computer Science } \\
\text { - } & \text { Library Management } \\
\text { - } & \text { Information Institutions Management Fundamentals } \\
- & \text { Libraries and Society }\end{array}$ \\
\hline $\begin{array}{c}\text { Czech } \\
\text { Republic }\end{array}$ & $\begin{array}{c}\text { Masaryk } \\
\text { University Brno }\end{array}$ & $\begin{array}{l}\text { Information and Library } \\
\text { Studies } \\
\text { BA, MA, PhD }\end{array}$ & $\begin{array}{ll}- & \text { Library Processing and Services } \\
- & \text { Intellectual Property and Information Activity } \\
- & \text { Information Science } \\
- & \text { (Information Security, Information Systems, Information } \\
& \text { Education) }\end{array}$ \\
\hline France & $\begin{array}{l}\text { Institute of Technology } \\
\text { Paris Descartes }\end{array}$ & $\begin{array}{c}\text { DUT } \\
\text { Universal Technical } \\
\text { Diploma }\end{array}$ & $\begin{array}{ll}- & \text { DUT Information Communication } \\
- & \text { Book Trade }\end{array}$ \\
\hline Germany & $\begin{array}{c}\text { Humboldt } \\
\text { University in Berlin }\end{array}$ & $\begin{array}{l}\text { Library and Information } \\
\text { Sciences } \\
\text { BA, MA } \\
\text { Information Management } \\
\text { BA, MA }\end{array}$ & $\begin{array}{ll}- & \text { Digital libraries } \\
- & \text { Bibliometry, Infometriya, Scientometrics, } \\
- & \text { Information Policy, Ethics, Law } \\
- & \text { Information Retrieval and Exchange of Information } \\
- & \text { Communication and Management of Information and } \\
& \text { Knowledge }\end{array}$ \\
\hline Germany & $\begin{array}{l}\text { Hochschule der Medien } \\
\text { in Stuttgart }\end{array}$ & $\begin{array}{l}\text { Library and Information } \\
\text { Management } \\
\text { BA, MA }\end{array}$ & $\begin{array}{l}\text { - } \quad \text { Management in Human Resources, Organization, Marketing } \\
\text { - } \quad \text { Information and Media Market } \\
\text { - } \quad \text { Library Management System Database }\end{array}$ \\
\hline Hungary & University of Szeged & $\begin{array}{l}\text { Library and Information } \\
\text { Science } \\
\text { BA, MA }\end{array}$ & $\begin{array}{ll}\text { - } & \text { Library Organization, Library System } \\
- & \text { Management of Technological Resources } \\
\text { - } & \text { Document Management } \\
\text { - } & \text { Legal Institutions of Documentation. }\end{array}$ \\
\hline Lithuania & $\begin{array}{l}\text { Vilnius University, } \\
\text { Institute of Library and } \\
\text { Information studies }\end{array}$ & $\begin{array}{l}\text { Information Management } \\
\text { in Libraries } \\
\text { BA, MA, PhD }\end{array}$ & $\begin{array}{ll}\text { - } & \text { Information and Library Service } \\
\text { - } & \text { Information Science } \\
\text { - } & \text { Culture Information and Communication } \\
\text { - } & \text { Creative Communication } \\
- & \text { Business Information Management } \\
- & \text { Public Relations }\end{array}$ \\
\hline Poland & $\begin{array}{c}\text { Jagiellonian } \\
\text { University in Krakow, }\end{array}$ & $\begin{array}{l}\text { Management and Social } \\
\text { Communication } \\
\text { BA, BSc, MA, PhD }\end{array}$ & $\begin{array}{ll}\text { - } & \text { Information and Library Sciences } \\
- & \text { Culture and Media Management } \\
- & \text { Electronic Information Processing } \\
- & \text { Management } \\
- & \text { Social Policy }\end{array}$ \\
\hline Turkey & $\begin{array}{c}\text { Hacettepe University in } \\
\text { Ankara }\end{array}$ & $\begin{array}{c}\text { Information Management } \\
\text { BA, MA, PhD }\end{array}$ & $\begin{array}{ll}\text { - } & \text { Information Management } \\
- & \text { Information Architecture } \\
- & \text { Records and Database Management } \\
- & \text { Information Literacy, Standards and Cooperation in Information } \\
& \text { Management. }\end{array}$ \\
\hline
\end{tabular}

important influence had our joint work in the frame of Erasmus Intensive Programmes with our partners- the leading European universities, engaged in similar training programs in the field of LIS education. Table 3 presented the basic information about our partner's programs.

Review of the main directions in which are trained future library and information managers can generally be limited to the following: Information and Communication Technology and Resources; Information and Library Management (in particular-Management of Information Services, Management Information Systems, Personnel Management); Knowledge Organization. Academic subjects included in these directions are different for different universities.

\section{Findings for Future Curriculum Review}

A detailed analysis of the information from this research leads to interesting conclusions that will be very useful 
for future curriculum review of the "Library and Information Management". We achieved some findings and solutions that we suggest to the attention of the LIS academic community worldwide as useful and relevant to the context of modern educational paradigm.

Special attention in this article we would like to devote to the fact that some academic subjects which are included in the curriculum of SULSIT and met student's interest do not exist or are very limited in the curricula of universities abroad. The development and integration of these disciplines in our educational plan is provoked by the interaction with prospective employers that define this knowledge as important and necessary for library and information professionals.

We draw attention to the following subjects:

- Intellectual Property;

- Standardization in Library Activities;

- Quality Management in Library and Information Activities;

- Library Psychology;

- Bibliotherapy.

\subsection{The Training on Intellectual Property}

In an knowledge based economy, an important place take experts who can interpret issues related to intellectual property, such as librarians and information specialists. It is they who are responsible for creating a policy of promoting understanding and resolving legal disputes and conflicts that are unique to this aspect of the Information Society [16]. One way to achieve this is through the educational impact of the curriculum on intellectual property. Intellectual property can be considered as an element of information literacy in university information environment, so to develop successfully students at the university, and in life, they must learn to use efficiently and effectively the wide variety of information and communication technologies for searching, finding, organizing, analyzing and evaluating the information they need. In addition, they need to understand the ethical use of information, including the violation of individual rights to intellectual property as plagiarism, use without permission of the author of works of literature, art, science, and also of patented inventions, industrial designs, indications (trademarks, geographical indications, domain names, companies). Finally, they should be able to systematize all this knowledge together to create an effective final product. This requires them to assemble the entire package of basic skills for research, technological skills, critical thinking and evaluation.

\subsection{The Training on Standardization in the Library Activities}

Knowledge of standardization and specific standards in all areas of human activity are not only useful but also necessary in the direct work of specialists and leaders in different organizational structures, including libraries. Learning of this discipline implies a successful career of students and saves them a lot of effort, time and resources to achieve and implement the requirements, rules, standards, approaches, methods and etc., established by the most highly qualified professionals at international, European and national level and involved in the development of these standards.

Among the most common library standards that future library managers in SULSIT learn about can be mentioned:

- BGS ISO 11690:2013 Information and documentation—Library performance indicators.

- BGS ISO 2789:2012 Information and documentation-International library statistics.

- BGS ISO 15511:2012 Information and documentation —-International standard identifier for libraries and related organizations (ISIL).

- BGS ISO 5127:2009 Information and documentation-Vocabulary.

- BGS ISO 2709:2011 Information and documentation—Format for information exchange.

- BGS ISO 25577:2012 Information and documentation-MarcXchange.

- BGS ISO 3166-1:2006 Codes for the representation of names of countries and their subdivisions-Part 1: Country codes.

- BGS ISO 11799:2008 Information and documentation—Document storage requirements for archive and library materials.

Standardization in Library Activities discipline, taught in the sixth semester is fundamental for studying in the seventh semester Quality Management in Library and Information Activities. 


\subsection{The Training on Quality Management in Library and Information Activities}

The educational content in this course is structured in two parts:

Fundamental part, which includes the following topics: the importance and relevance of quality management; historical development, total quality management, principles of quality management, principles for analysis, security, control, organization, systems for quality management standards, quality management.

Today more libraries develop and implement systems for quality management. The most commonly used worldwide are those based on a series of international standards ISO 9000 [17]. Therefore lead in the course lectures Quality management in library and information work is devoted to this particular system.Are also presented two other systems for quality management application in libraries_-Balanced Scorecard (BSPE) and selforganizations under the criteria of the European Foundation for Quality Management (EFQM).

Specialized part, consistent with the professional field in which to be realized students in "Library and Information Management." This part of the curriculum content provides knowledge, documentation and implementation of systems for quality management in libraries and information centres, in view of their professional activity. The seminars helped to give young professionals skills to formulate the mission of the library, and the ensuing quality policy and objectives to achieve quality. Special emphasis on the brainstorming technique of K. Ishikawaas an opportunity to identify the causes of a problem and their elimination [18]. Students are introduced to the documentation requirements of the quality management system, and sample content of the basic documents of the Quality Management System (QMS), which adapts to the specific type of library.

\subsection{The Training on the Library Psychology}

The problem of improving the quality of library services at the level of librarians' professionalism today is extremely topical. These factors increase their need for psychological and pedagogical knowledge.

The course on Library Psychology aims to equip students with true understanding and knowledge of the nature, functions and principles of Psychology, as part of the activities in the library environment to provoke new ways of working and communicating with users of library services. The course content is divided into two main modules. In the first module “Library Psychology" is considered library psychology as a scientific and academic discipline, traced the historical development of library psychology, the role of books in modern society. In the second module "Psychology of Communication in the Library" focuses on issues of personal and professional qualities of the library specialist; the psychology of communication between Librarian and Reader; the peculiarities of psychological climate in the library team and theformation steps of an effective team in the library; the nature and style of the library manager. Library Psychology has significant potential, not only theoretically, but practically oriented knowledge useful in the work of librarians from different types of libraries.

\subsection{The Training on the Bibliotherapy}

The course provides theoretical and practical knowledge to the students about the nature and application of Bibliotherapy in libraries. Students learn the historical and scientific development of Bibliotherapy. The Bibliotherapy brings together at least three fields of knowledge - a Science Studying the Book (Book Science, Literature, Library), the Science of the Human Soul, Targeted Bibliotherapy (Medicine, Psychiatry, Psychotherapy, Rehabilitation) and the Science of reading, (Ensuring Efficiency of Bibliotherapy, Psychology of Reading, Reading Instruction), which makes it extremely useful in the training of students. The lectures aim to examine possibilities which reveal Bibliotherapy by presenting its various forms, methods and functions. The students learn about new and alternative forms of employment applicable in the library environment.

The course includes the following three aspects: first module "Origin and Nature of Bibliotherapy" which focuses on the scientific development of bibliotherapy, definition of bibliotherapy, determining bibliotherapy, the types and purposes, her functions and tasks. In the second module, “Applications of Bibliotherapy” are tracked innovative techniques used by library professionals, bibliotherapy as a form of working with children with special needs. The third module, "Fairy Tales Therapy" is a brand new in Bulgaria and for the first time available as part of an academic course. In it, students get acquainted with the possibilities of therapy tales methodological model of working with stories, kind words and ways of working with them.

Bibliotherapy is dynamic and flexible science for support, encouragement, challenge, identifying and addressing a number of significant problems in modern society. It is a mechanism for painless reach the soul and 
the possibility of achieving lasting results and as such may be extremely useful in the training of future specialists.

\section{Discussion}

In the present article, we pay attention to the above mentioned disciplines, as the analysis of the curricula of many universities around the world has shown that these disciplines are still rarely studied. In Table 2 and Table 3, Universities which studied one or more than one of the subjects on which we focus are present. Relatively new disciplines are presented by us, consistent with the requirements of the modern information society, and the role and functions of libraries in it. We believe that along with the subjects proved important for the preparation of future LIS professionals as library management, library legislation, library marketing, etc. would be appropriate curricula to attend and complementary knowledge of library professionals, consistent with the current state of society and libraries. The information presented can be used by other universities in Europe and beyond for comparison and analysis.

\section{Conclusion}

Through active partnerships with foreign universities, innovative teaching methods appropriate to the training of future specialists disciplines, and the continuous enrichment capacity and experience of the faculty, trained students in specialty "Library and Information Management"-we aim to be one of the leading educational institutions and adequate to the modern needs. We hope that shared insights and achievements will provoke an open professional dialogue for the enrichment of library and information academic programs. This collaboration could be going on together with the LIS community dialogue about IFLA Trends and the future of libraries and librarian profession in general [19].

\section{Acknowledgements}

This publication has been realized under the project "Development of an information environment to motivate and stimulate young researchers in SULSIT” by Contract: BG051PO001-3.3.06-0055. The project is funded by the Operational Programme "Human Resources Development” SchemeGrantsBG051PO001-3.3.06 "Support for the development of PhD students, post graduate students and young scientists" funded by the European Social Fund of the European Union.

\section{References}

[1] Kajberg, L. (2008) The European LIS Curriculum Project: Findings and Further Perspectives. Zeitschrift für Bibliothekswesen und Bibliographie, 55, 184-189.

[2] Juznic, P. and Badovinac, B. (2005) Toward Library and Information Science Education in the European Union: A Comparative Analysis of Library and Information Science Programmes of Study for New Members and Other Applicant Countries to the European Union. New Library World, 106, 173-186. http://dx.doi.org/10.1108/03074800510587372

[3] Georgy, U. (2009) Internationalization of LIS Education within the Bologna Process-Mobility and Flexibility. IFLA, Milano. http://www.uas7.org

[4] Kawalec, A. (2014) Education, Competencies, Skills in the Field of Information and Library Science in Europe. Library (R)evolution: Promoting Sustainable Information Practices: Abstracts of the 22nd International BOBCATSSS symposium, 29-31 January 2014, Barcelona, 16. http://bobcatsss2014.hb.se/wp-content/uploads/2014/01/Bobcatsss-abstract-book.pdf

[5] LIS Education in Europe. http://www.iva.dk/LIS-EU/project.asp/

[6] Kajberg, L. and Lørring, L. (2005) European Curriculum Reflections on Library and Information Science Education. The Royal School of Library and Information Science, Copenhagen, 241 p. http://www.library.utt.ro/LIS Bologna.pdf.

[7] Pannier, G., Wilhelm, H. and Todorova, T. (2011) IPBib: Das Grimm-Zentrum-(k)ein Bibliotheksmärchen. Mobility and Innovation in the European Context. Proceedings of Evaluation Conference on ERASMUS Intensive Programmes, Federal Ministry of Education and Research, Bonn, 2011, 19-21.

[8] Project Website (2013) Erasmus Intensive Programme "Library, Information and Cultural Heritage ManagementAcademic Summer School”. http://libcmass.unibit.bg/ 
[9] Todorova, T. (2012) Library, Information and Cultural Heritage Management: Textbook. Za bukvite-O Pismeneh, Sofia, 246.

[10] Todorova, T., et al. (2013) The Changing Role of the Manager in the Digital Era: Findings from Erasmus IP LibCMASS 2012 Project in from Collections to Connections: Turning Libraries “Inside-Out”. Proceedings of the 21th International BOBCATSSS Conference on Information Science in Ankara, Ankara, 23-25 January 2013, 202-204. http://bobcatsss2013.bobcatsss.net/proceedings.pdf

[11] (2013) UNESCO Chair ICT in Library Studies, Education and Cultural Heritageat State University of Library Studies and Information Technologies. http://unesco.unibit.bg/

[12] Yankova, I. (2009) Library Management and New Challenges in Digital Era in Libraries and Their Clients: Free or fee Services Supporting Social Communication in Digital Era. Proceedings of the ePublications of the 15th Jubilee International Conference of JU LIS Institute in Kraków, Poland, 76-80. http://skryba.inib.uj.edu.pl/wydawnictwa/e06/yankova.pdf

[13] State University of Library Studies and Information Technologies. http://www.unibit.bg/learning-activity/bachelor/bachelor-plans.

[14] Parizhkova, L. (2013) The Book Our More Sensual Present: Textbook. Za bukvite-O Pismeneh, Sofia, 248.

[15] Trencheva, T. and Eftimova S. (2013) Intellectual Property at the Universities-Creativity: The Next Generation. Textbook. Zabukvite-O Pismeneh, Sofia, 206.

[16] Joint, N. (2006) Teaching Intellectual Property Rights as Part of the Information Syllabus. Library Review, 55, 330336. http://dx.doi.org/10.1108/00242530610674730

[17] Balague, N. and Saarti, J. (2011) Managing Your Library and Its Quality: The ISO 9001 Way. Chandos, Cambridge. http://dx.doi.org/10.1533/9781780632797

[18] Ishikawa, K. (1990) Introduction to Quality Control, 3A Corporation, Tokyo.

[19] (2013) IFLA Trend Report. http://trends.ifla.org/ 
Scientific Research Publishing (SCIRP) is one of the largest Open Access journal publishers. It is currently publishing more than 200 open access, online, peer-reviewed journals covering a wide range of academic disciplines. SCIRP serves the worldwide academic communities and contributes to the progress and application of science with its publication.

Other selected journals from SCIRP are listed as below. Submit your manuscript to us via either submit@scirp.org or Online Submission Portal.
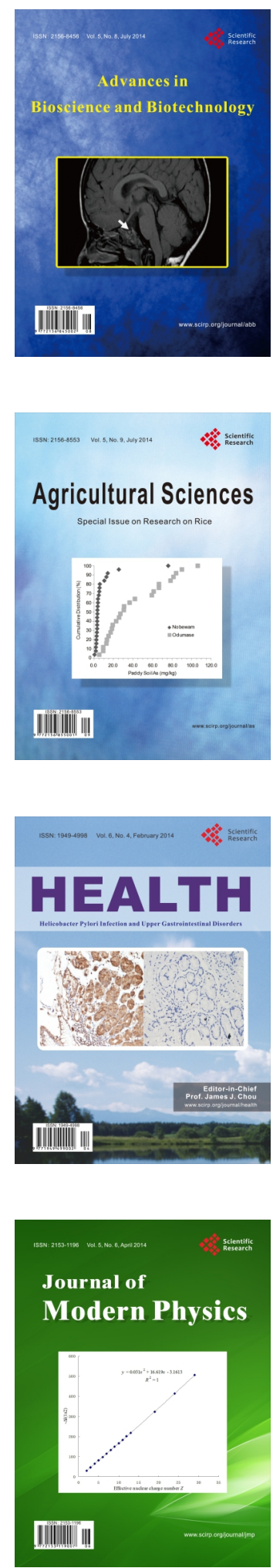
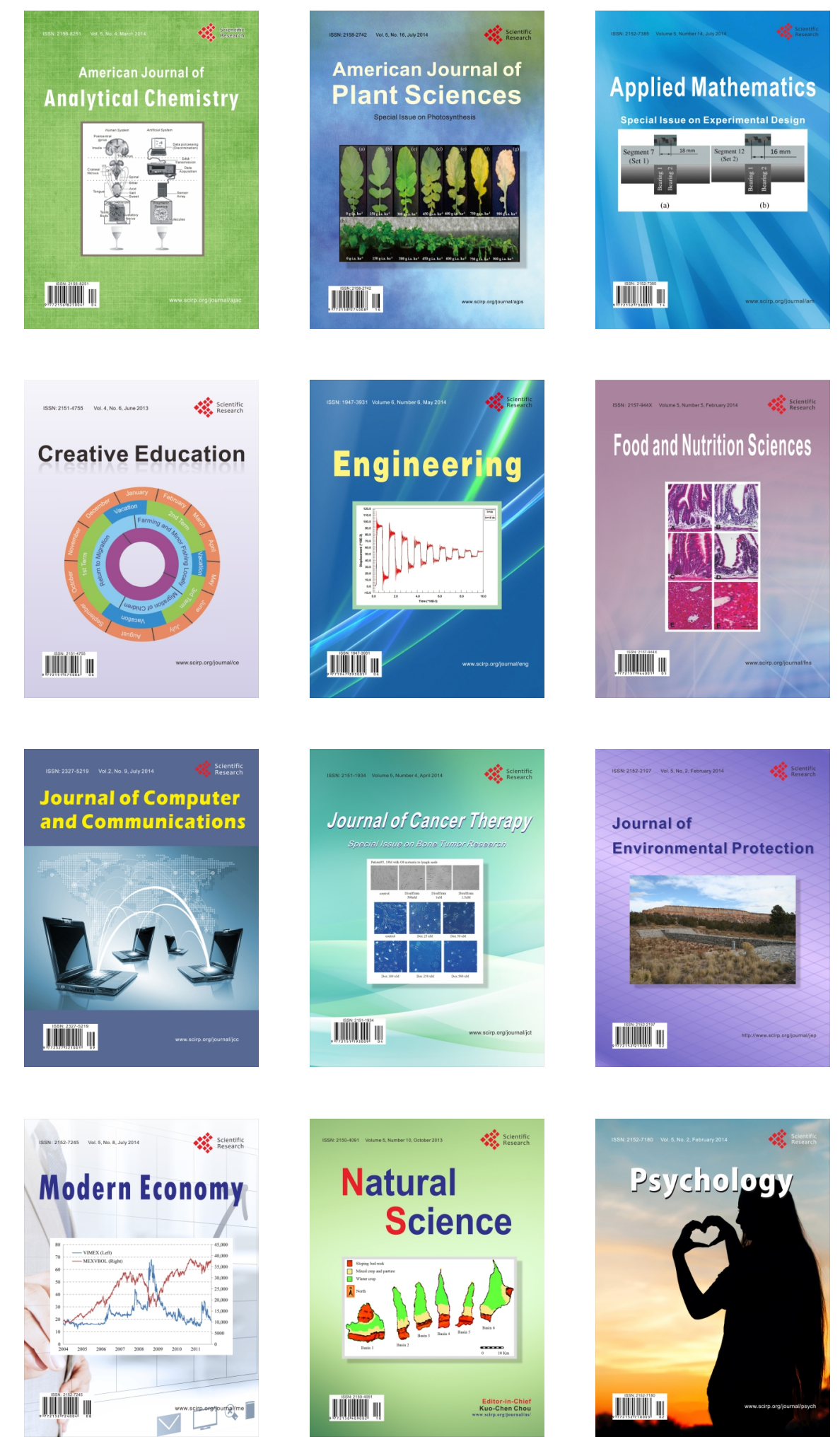